\title{
Multi-criteria Evaluation in Strategic Environmental Assessment in the Creation of a Sustainable Agricultural Waste Management Plan for wineries: Case Study: Oplenac Vineyard
}

\author{
Boško Josimović ${ }^{1}$ Nikola Krunić ${ }^{\text {}}$ Aleksandra Gajić ${ }^{1}$ · Božidar Manić1
}

Accepted: 30 January 2021 / Published online: 23 February 2021

(c) The Author(s) 2021

\begin{abstract}
Strategic Environmental Assessment (SEA), as a support to strategic planning, is a starting point in the creation of a sustainable concept of managing waste that is based on the principles of a circular economy. The role of SEA is to guide the planning process towards the goal of securing the best effects in relation to the quality of the living environment and the socio-economic aspects of development. SEA is also an instrument that can be used when making optimal decisions about spatial development, which further contributes to its importance and role in the planning process. The implementation of SEA allows developers to establish the benefits and implications of the proposed spatial changes, taking into account the capacity of the space to sustain the planned development, and to determine the degree of acceptability of the proposed spatial changes. This paper presents a specific method used for impact assessment in SEA for the Agro-Waste Management Plan (AWMP) for Oplenac Vineyard. The specificity of this method is that it combines specific goals, indicators and criteria for assessing the effect of planning solutions formulated in the simulated AWMP for Oplenac Vineyard using a semi-quantitative expert method. The results of the paper indicate the possibility of using GIS tools to increase objectivity in the expert evaluation of planning solutions, particularly in relation to a group of criteria for assessing the spatial dispersion of the impacts. This reduces the subjectivity that is characteristic of all expert methods. The graphical presentation of the results in GIS technology and the use of matrices and graphs to present the results makes them easier to understand and creates a good basis for making optimal decisions on future activities concerning the elimination of waste from wineries and viticulture. The research was carried out within the framework of the NoAW project, which is supported by the European Commission through the Horizon2020 research and innovation program.
\end{abstract}

Keywords Multi-criteria evaluation (MCE) - Strategic Environmental Assessment (SEA) - Agricultural waste $\cdot$ GIS tools 


\section{Introduction}

In the current social, economic and environmental circumstances in which humanity finds itself today, and in which profit is often seen as the only measure of success and development, ethical and moral issues related to carrying out many human activities are becoming increasingly important. The issue of the rational use of the planet's resources, while satisfying the growing socio-economic needs of the population, therefore stands out as being both important and challenging. Under such circumstances, every kind of environmental protection contains an ethical and moral component that allows us to make choices that have the ultimate goal of humanizing relations towards the resources and natural values of our planet, as written about by numerous authors (Buttel 1996; Callicott 2018; Dzwonkowska 2017; Fahlquist 2009; Keong 2021; Miller 2018; and others).

Today, the concept of environmental protection is involved in almost all areas of development, including agriculture or agricultural waste management planning, based on the principles of a circular economy with the support of SEA, which is the subject of this paper. The aim is to conceptualize environmental protection as an answer to the ethical and moral questions and dilemmas related to development. It is based on the optimization of development (economic) through the minimum use of the planet's non-renewable resources, on one hand, and a sustainable environmental balance through the preservation of basic environmental factors, on the other.

As an example, we can cite the concept of the circular economy, in which all goals and principles are reduced to four words-waste as a resource. Waste that is not thrown away, and therefore does not pollute the environment, is used instead as a resource that brings profit by its reuse in the production of energy, cosmetics, and various products, as well as in food. It promotes competitiveness and innovation, at the same time protecting the environment and enabling economic growth, thus contributing to resolving ethical and moral dilemmas in related fields.

Returning to the subject of this paper, we can say that by applying SEA in the planning process it is possible to see the implications of planned activities and the spatial scale of expected changes in space and in the environment. In this way, it is possible to influence the making of ethical and moral decisions on development, based on the consideration of social, economic and environmental aspects of sustainable development, in which priority is given to environmental protection.

By applying SEA in the planning process, it is possible to see the implications of the planned activities and the spatial scale of the expected environmental and spatial changes. A large number of authors have discussed the role and importance of SEA in designing policies in various spheres of social activities, as well as its role in decision-making (Nilsson and Dalkmann 2001; Maričić and Josimović 2005; Nilsson et al. 2005; White and Noble 2013; Josimović et al. 2015; Unalan and Cowell 2019; and others). Therefore, it is not surprising that a growing number of international institutions, such as the European Commission, the World Bank, UNDP, UNEP, USAID and others, are introducing a requirement 
for SEA to be used, with the idea for development initiatives to be in line with the goals of environmental protection and the principles of sustainable development. This shows the scientific and professional importance of using SEA when making development policies (for more details, see: Dalal-Clayton and Sadler 2005; Chaker et al. 2006; Noble and Nwanekezie 2017).

Compared to other methods which contribute to decision making, such as the traditional "life cycle assessment" (Laurent et al. 2013; Ahlgren et al. 2015; Hanandeh and Gharaibeh 2016; O'Brien et al. 2016; Rugani et al. 2019; Acosta-Alba et al. 2019), SEA contributes to integrating the impacts at the strategic level of planning. For the purpose of making good decisions regarding the sustainability of planning solutions, it is necessary to consider different aspects of the potential impacts.

The application of SEA is possible, and necessary, in various areas of spatial development such as: spatial and urban planning; agriculture; forestry; water management; energy; waste management; etc.; and a significant number of authors have recognized this and written about it (Ananda and Heralth 2009; Balfors et al. 2018; Brown and Therivel 2000; Josimović 2020; Josimović et al. 2021; Nenković-Riznić et al 2014; Salhofer et al. 2007; Stefanović et al. 2018; and others). The areas of application for SEA are also established in the Directive on the assessment of the effects of certain plans and programmes on the environment (Directive 2001/42/ EC), and then in the legislation of European countries relating to the environment.

However, not much has been written in scientific literature about the application of SEA in agricultural waste management planning, agricultural land use planning, and the application of multi-criteria evaluation and analysis in agricultural decision making, even though some authors highlight its role and significance (Tzilivakis et al. 1999; Biarnès et al. 2009; Jakku and Thorburn 2010; Leite et al. 2015; Kamali et al. 2017; Um et al. 2018; Jeong 2018).

If we look at agricultural waste management research as a pyramid, the base of that pyramid is strategic planning with the support of the SEA process, and the top of the pyramid, which is reached by means of various techniques and procedures that represent the logical continuation of the SEA process, is a particular product or solution that leads to the elimination of waste. In this context, the application of SEA is the starting point for achieving goals in the field of the circular economy, because right from the earliest planning stage, SEA indicates the changes and expected benefits to the environment and the economic sphere from applying the principles of a circular economy. In this way, decision makers (entrepreneurs, investors, etc.) can understand and recognize all the positive aspects of the circular economy, on the basis of which they will make decisions about the future treatment of the waste produced. Here, it is especially important to point out the possibility of making a profit as the dominant driver of entrepreneurial initiatives, from which 
another important benefit will also be achieved during the implementation of the initiative-environmental protection.

The subject of this paper is to apply the multi-criteria evaluation method (MCE $\left.{ }^{1}\right)$ in the process of SEA for the simulated AWMP for the Oplenac Vineyard (case study), supported by a Geographic Information System (GIS). GIS has an increasing and notable role in viticulture. It is becoming a basic tool in the analysis of the suitability of terrain for forming vineyards, combining numerous and complex natural conditions (topography, soils, land zoning, and climate) and expert opinion, thus forming new knowledge bases for successful vineyard management models (Jones et al. 2004; Jurisic et al. 2010; Arnaudova and Bileva 2011; Coulon-Leroy et al. 2013; Nowlin and Bunch 2016; Badr et al. 2018). The aims of this study are: the development of methodology that increases objectivity in the process of evaluating planning solutions; simple presentation of the results for the purpose of decision making; and highlighting the importance of understanding agricultural waste as a resource, the elimination of which has multiple positive effects on the environmental quality and socio-economic development factors.

The research was carried out within the NoAW project, which is supported by the European Commission through the Horizon2020 research and innovation program. Bearing in mind the terms of the $\mathrm{H} 2020$ Horizon NoAW project, based on a nearzero-waste society and the promotion of a circular economy in agro-waste management, one part of this interdisciplinary study has been dedicated to assessing the territorial impact of an AWMP on the environment in the strategic planning of agrowaste management. At the level of strategic planning, the objective of the territorial impact assessment is directly connected with the decision-making process, which is an important step towards sustainable solutions. Such processes make it possible to direct the planning and management of agro waste in the earliest phase of conceptualizing the development possibilities (in the organizational phase that precedes the act of choosing the processing and re-usage technology or the agro-waste elimination technology).

\footnotetext{
${ }^{1}$ Development of the MCE method is linked with the beginning of the 1970s and today it is considered as a well-developed and widely applied scientific method which is still being developed and supported by numerous references (Kangas and Kangas 2005; Ananda and Heralth 2009; Josimović et al. 2015). When first developed, MCE was characterised by the methodological principle of multi-criteria decision-making (MCDM) with little or no participatory mechanisms included (Zionts and Wallenius 1976; Zionts 1979). Development of the method led to the application of the multi-criteria decision aid (MCDA), in which the quality of the decision-making process became central. Studies started to point out the need to include public participation in MCE, thus fostering the emergence of participatory multi-criteria evaluation (PMCE) (Banville et al. 1998; De Marchi et al. 2000; Proctor and Drechsler 2006) and social multi-criteria evaluation (SMCE) (Munda 2008). In this context appropriate deliberation is a prerequisite to assuring a quality outcome. The MCE method is nowadays often advised as a convenient support in the decision-making process because of its capacity to point out multiple alternatives of development in many ways on the basis of assessing criteria related to the environment and socio-economic aspects of sustainable development (Sarkkinen et al. 2019).
} 


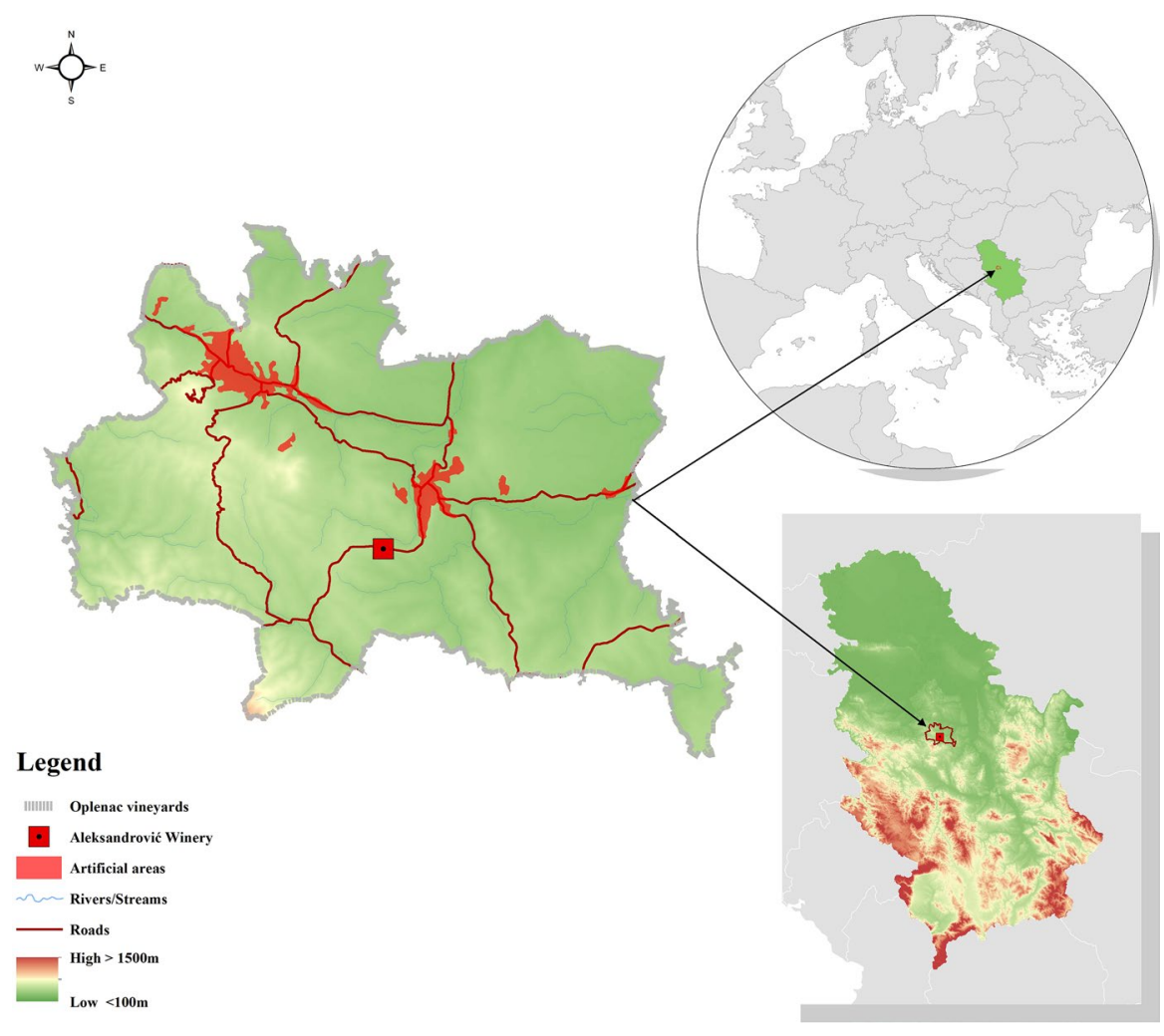

Fig. 1 Location of Oplenac Vineyard and WA

\section{Case Study Area-Initial Position}

Within the framework of the interdisciplinary NoAW project based on the principles of a circular economy, several options for eliminating different types of agricultural waste were analyzed. One of these options was to analyze the possibilities for eliminating waste from wineries and viticulture. The initial phase in the elimination of agricultural waste was to create an AWMP with the support of the SEA process, which is a key instrument for guiding the planning process towards the goals and principles of a circular economy.

The Aleksandrović Winery (AW) from Topola (Serbia) was chosen as the case study; it is also one of the partners in the project. AW belongs to the Sumadija region, which is considered to be a functional wine-growing region. This region has approximately one small and 10 active large wineries in 9 municipalities. It is divided into several wine-growing sub-regions (vineyards), and the Oplenac Vineyard (where AW is located) is an area of special research interest (Fig. 1).

AW was selected as a representative case study since it is a leading winery according to: the area covered by its vineyards ( $75 \mathrm{ha}$ ), its wine production and its 
production of waste. The research concept and methodology for the assessment of AW's territorial impacts was applied to the wider territory of Oplenac Vineyard ( 8 wineries, and 137 ha covered by vineyards). By applying the principle "think regionally, act locally", the data obtained in AW were extrapolated to the region of Oplenac Vineyard (wine-making sub-region) thus creating the postulate for regionalization in waste management (regionalization is almost always economically justified). On the other hand, the role of SEA as an instrument applied at the level of strategic planning (national, regional, sub-regional) is justified in the initial phase of implementing the concept of sustainable waste management. The extrapolated data on the production of waste from wineries and viticulture in Oplenac Vineyard were supplemented by precise data obtained from the employees working at wineries in this sub-region. In this way, more reliable data were obtained.

Another reason for choosing this research area was that existing practice in waste management is not in line with contemporary principles, and in particular it is not in line with the principles of a circular economy, which a number of authors have written about in recent years (Kirchherr and Piscicelli 2019; Peiró et al. 2019; Sassanelli et al. 2019; Suarez-Eiroa et al. 2019), and which the modern theory and practice of waste management are based on. Waste is not treated as a resource, it is disposed of without pre-treatment in inadequate locations, pruning waste is left in large quantities in vineyards, and the environment is put under pressure. The selection of this research area offers various possibilities and contributions when forming the AWMP and during the SEA process. As a rule, the greatest contribution is made in areas that are not completely regulated, because there are more problems that need to be addressed in the research or pointed out through the SEA process. In this context, SEA shows itself to be an instrument for educating researchers and professionals.

The continuation of this paper presents the MCE method (multi-criteria evaluation) applied in the implementation of the SEA process for the simulated ${ }^{2}$ AWMP for Oplenac Vineyard. Special emphasis was placed on the role of GIS in the assessment of the spatial dispersion of the impacts and presentation of the results.

\section{Methodological Framework}

The methodological approach to impact assessment in the SEA process is quite flexible with respect to the various precise mathematical and software tools used in environmental engineering and other fields, based on scientific postulates (Liou et al. 2006). A number of authors state that there is no general SEA methodology that applies to all types of plans. Moreover, SEA techniques and methodologies should be treated as a set of different methods and tools, any of which can be selected by a user depending on the specific circumstances (Brown and Therivel 2000; Balfors

\footnotetext{
${ }^{2}$ Since it was not feasible to formally develop an AWMP as part of the NoAW project, an AWMP simulation was conducted for Oplenac Vineyard for use with the MCE method in the SEA process. The simulation entailed defining the planning solutions included in the multicriteria evaluation process, which are an answer to existing waste management problems and are based on the results of the analytical phase.
} 


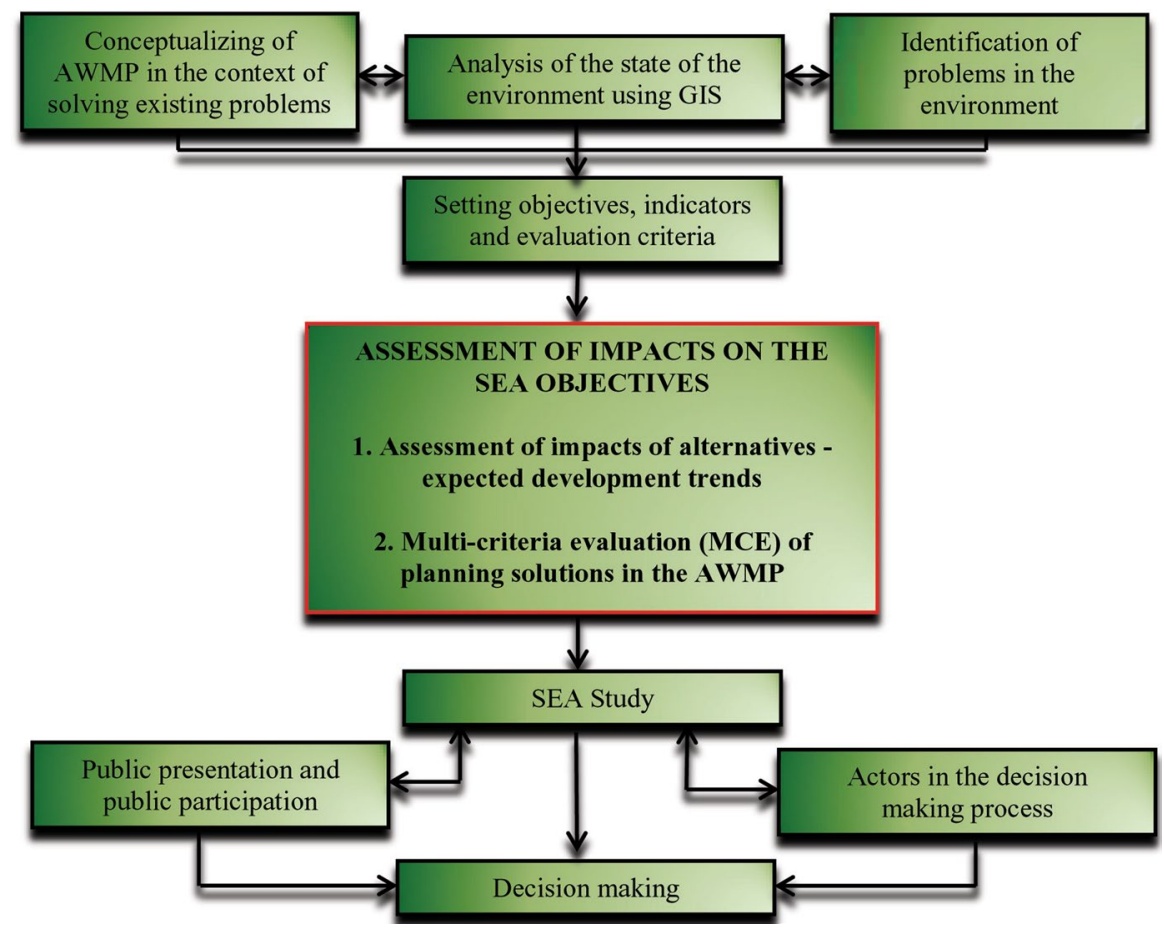

Fig. 2 Methodological framework for the SEA

et al 2018; Unalan and Cowell 2019). Marsden (2002) stated that, in terms of methodology, SEA dominantly relies on the qualitative method of expert impact assessment as opposed to traditional Environmental Impact Assessment (EIA), and therefore expert assessment, which always entails a certain level of subjectivity, plays a definitive role in it (Maričić and Josimović 2005). The issue of selecting the appropriate assessment techniques and methodologies used in any specific case must be dealt with by referring to adequate implementation experiences accumulated through comparative studies of past schemes and applications (Liou et al. 2006).

In the specific case of the SEA process for the AWMP for Oplenac Vineyard, a semi-quantitative method of multi-criteria expert evaluation of the planning solutions was applied as the basis for valorizing the space for sustainable spatial development (Josimović et al. 2015), in combination with GIS tools and the qualitative data obtained, which served as the basis for defining the evaluation criteria. This method has a few basic methodological steps (Fig. 2).

As shown in Fig. 2, the task in the initial phase of the SEA process was to analyze existing waste management practices in AW and Oplenac Vineyard, identifying key issues and their spatial and environmental implications. This analytical part was completed using GIS and collecting information and data in the field, including a data analysis on grape varieties, age, exposure of the vineyards, and so on, in order to make a prediction on the future production of waste. 
Bearing in mind the results of the analysis on the state of the environment, potential pollutants in the area and existing threats, the next stage was to formulate planning proposals in the AWMP, on one hand, and the SEA goals, indicators and criteria to assess the AWMP on the other. The planning proposals were formulated in response to the existing waste management problems. The SEA goals were defined in relation to environmental receptors including all aspects of sustainable development. For each SEA objective, one or more relevant indicators were defined (Table 1). The indicators were taken from the general set of UN indicators of sustainable development (2019) and the National list of environmental indicators (2011).

This was followed by an assessment of the impacts of the AWMP on the environment and the socio-economic elements of sustainable development which took place in two stages: 1. evaluation of the development scenarios ("business as usual" and "implementation of the AWMP"), with the selection of the more favourable development scenario; and 2. the application of MCE methods in the evaluation of the planning solutions (semi-quantitative method) to determine the ranks of the impacts. In both steps, the AWMP solutions were evaluated against the defined SEA goals, but the impact assessment criteria differed. The qualitative evaluation of the development scenario followed the positive $(+)$ and/or negative ( -$)$ trends expected in each development scenario, while in the MCE method several groups of criteria were used, within the framework of which the qualitative or quantitative evaluation criteria were determined (Table 2). One of the groups of criteria relates to the spatial dispersion of the possible impacts of the AWMP and it is in this section that the paper focuses on how the use of GIS tools can increase objectivity in the evaluation of planning solutions.

All of the SEA results are presented in the SEA study (also including guidelines for environmental protection and monitoring), on the basis of which, in a transparent process, decisions can be made to adopt, amend or reject the AWMP. Bearing in mind that the research was based on an AWMP simulation, this final phase of the SEA process was not formally implemented but was educative in character for vineyard owners in Oplenac Vineyard.

\section{Results and Discussion}

The use of GIS spatial data made it possible to reliably determine the spatial dispersion of the impacts of the AWMP proposal. GIS was also used in the analytical phase after the spatial data and waste production data were collected in AW (the case study), which were then extrapolated to the Oplenac Vineyard area. Based on the results of the spatial analysis it was established that the existing waste management practice in the vineyards in the area of Oplenac Vineyard had several key characteristics: (1) Waste from pruning stays in the vineyards and there is no further treatment of this type of waste; (2) Grape remains, and the grape skins and seeds are evacuated from the winery and disposed of in locations that are not envisaged or prepared for this purpose; (3) Packaging waste (glass bottles from wine tasting and vineyard fertilizer packaging) is taken to an existing municipal landfill that does 


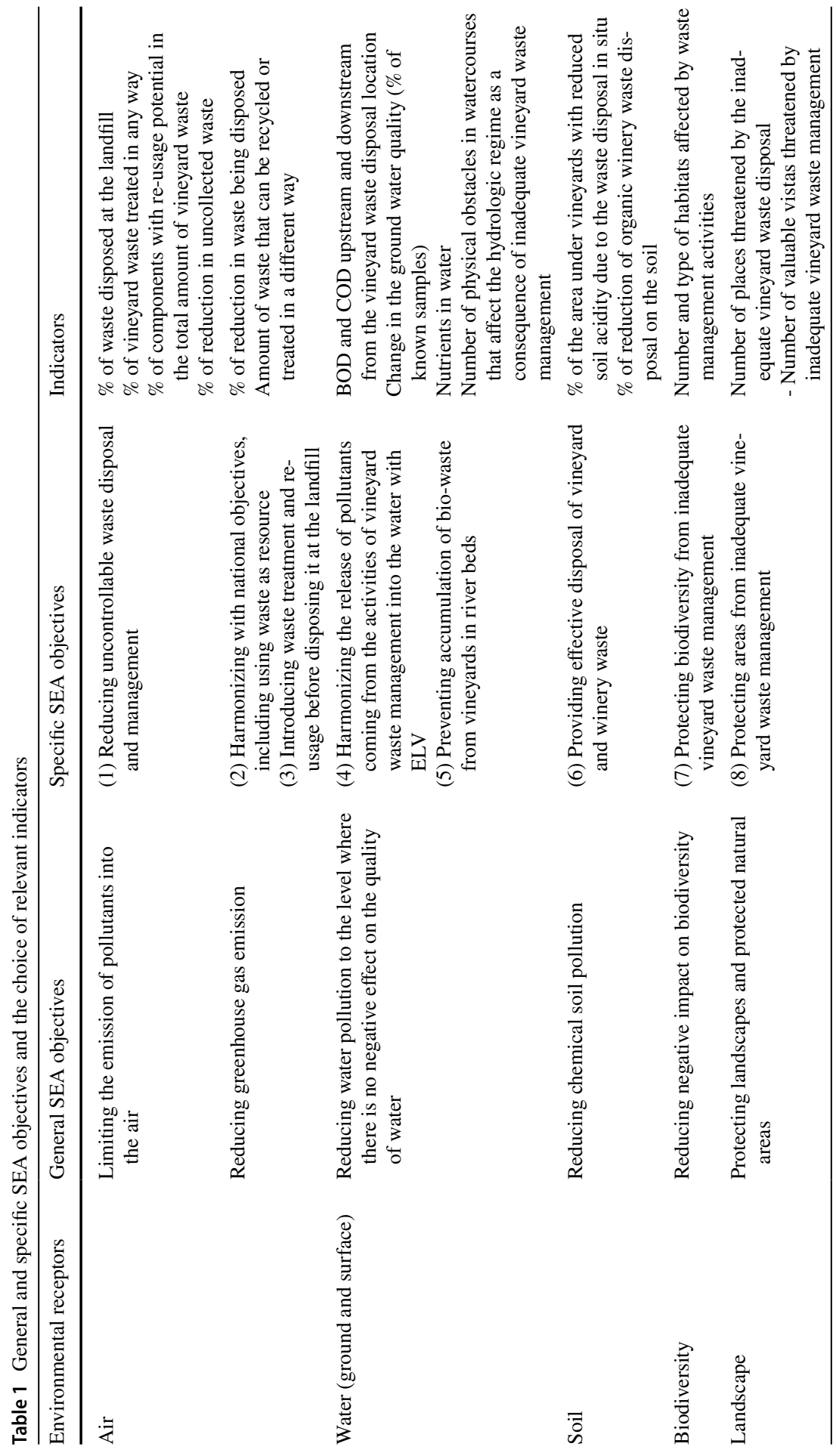




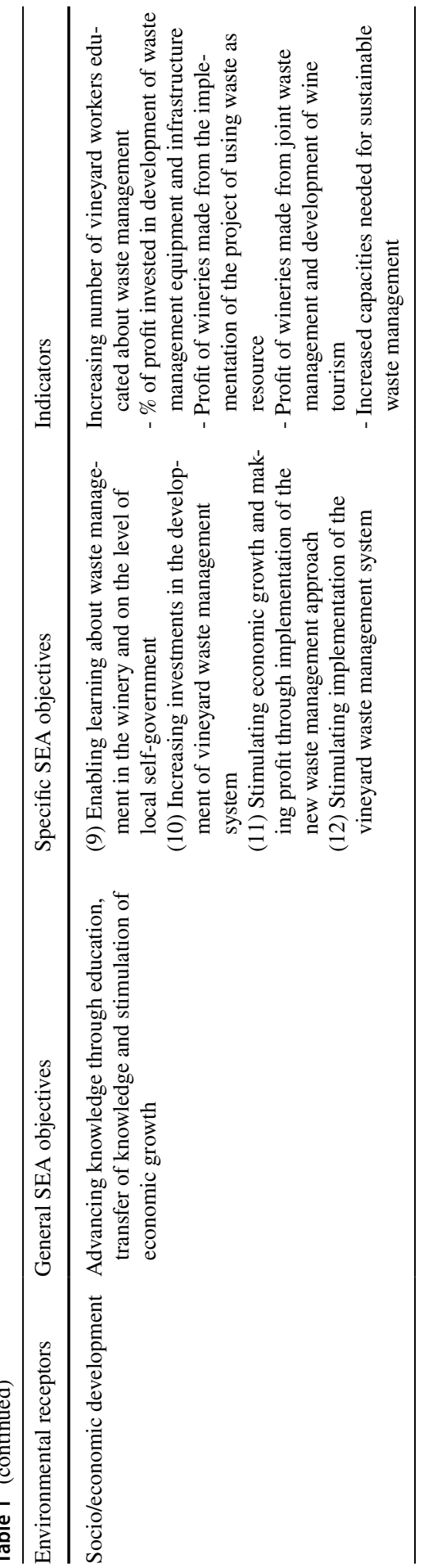




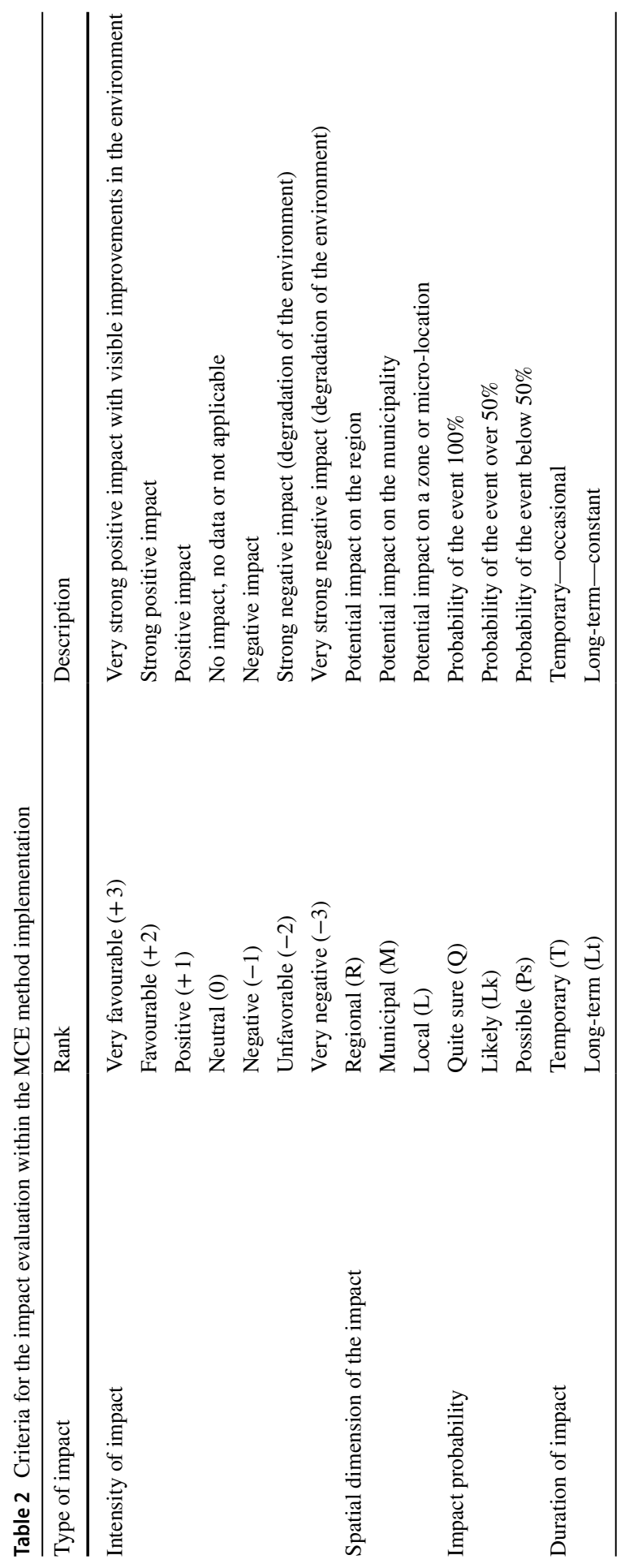


not have a recycling process; (4) Waste is not treated as a resource and no education program has been implemented on the importance and benefits of waste reuse; (5) Environmental problems as a result of existing practices in waste management are evident, especially in the period after pruning and grape harvesting, as this is when the largest amount of organic waste is produced.

These waste management practices in wineries in the area were used in the formulation of planning solutions for the AWMP for Oplenac Vineyard (first column in Tables 3 and 4), which is the response to the existing problems. They were also used for formulating the goals and indicators (Table 1) and evaluation criteria for the planning solutions and the AWMP (Table 2).

After the evaluation phase of the development scenarios ${ }^{3}$ confirmed that the scenario involving the implementation of Oplenac Vineyard AWMP was more favourable than the referential scenario-business as usual, the MCE method was applied. Matrices were formed that compared the planning solutions with the SEA goals and they were evaluated based on two groups of criteria: intensity of impact; and spatial dimension of the impact, bearing in mind that these two groups of criteria determine the significance and the strategic value of the impacts.

The key results indicate that the planning solutions from the AWMP almost exclusively provoke positive trends in space in relation to the SEA goals (Tables 3, 4, 5). Using MCE it was shown that the most positive effects from the implementation of the AWMP for Oplenac Vineyard are expected from implementing the planning solutions involving the regionalization of waste management and reuse of organic agricultural waste to obtain: energy, briquettes, composting, and various nutritional and cosmetic preparations; these are specifically developed in Table 5. The only negative effects identified during the MCE relate to the compensatory measures that winery owners should pay for all of the threats to the habitat which are not a result of applying the AWMP planning solutions, but rather are a consequence of waste management practices so far in Oplenac Vineyard.

The use of GIS tools and presentation of the results in the form of maps (Fig. 3), on which the negative, and later positive effects of applying the AWMP can be identified, made it possible to objectively determine the spatial dimensions of the impacts (local—covering only one vineyard, municipal—covering several vineyards within one municipality, regional—covering multiple municipalities).

The GIS analysis and presentation of the results of the SEA process for the Oplenac Vineyard AWMP demonstrate the contribution these methods make to understanding the importance of the changes that need to be made in the context of adopting sustainable waste management solutions. In this way, decision makers are

\footnotetext{
${ }^{3}$ Evaluation of the development scenario is not the focus of this paper and it has not been elaborated in detail. In short, it is concluded in this methodological step that the accepted development scenario involves the establishment of the concept of sustainable waste management based on the principles of a circular economy, regionalization and economy. With the implementation of the chosen waste development scenario, positive effects on all SEA (environmental and socio-economic) goals are expected. The use of organic agricultural waste as a resource, with all of its environmental and economic, direct and indirect impacts, would improve the existing state of the environment in Oplenac Vineyard and improve the image of wineries that produce that waste.
} 


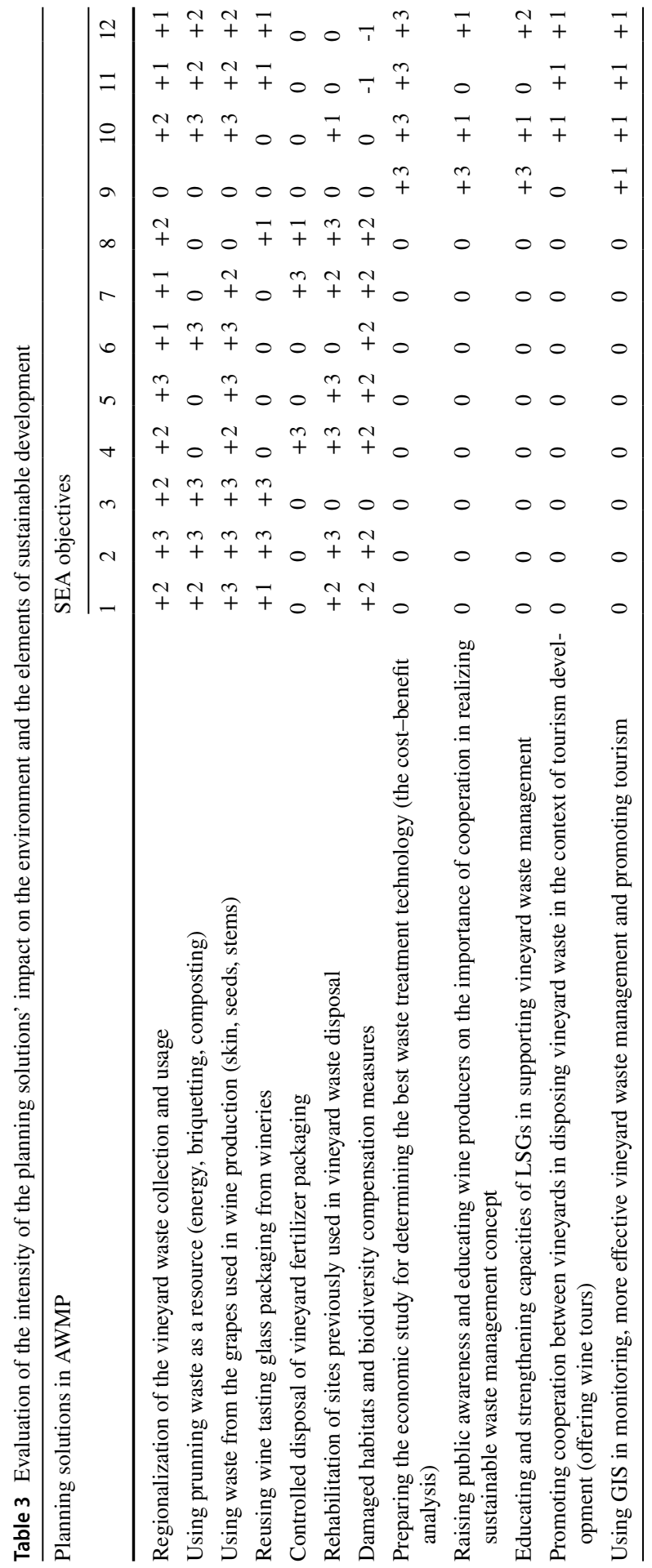




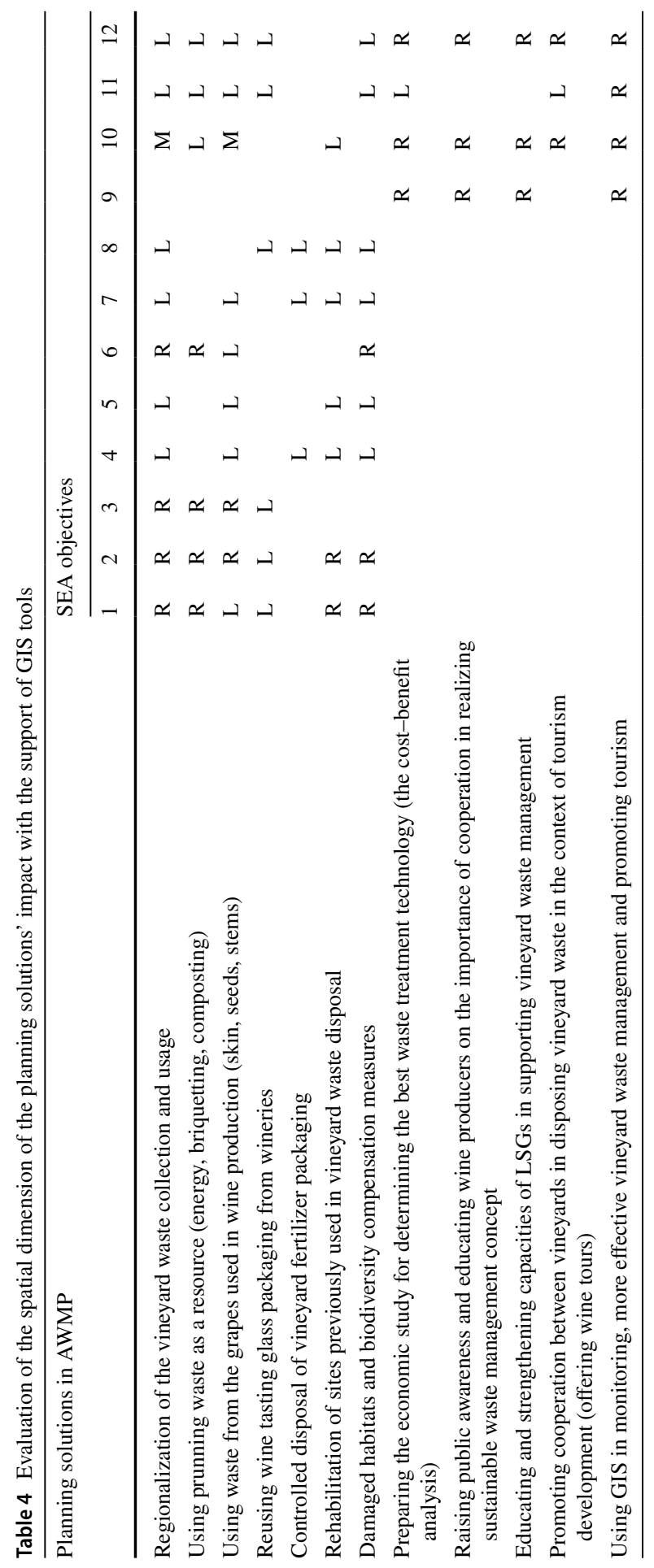




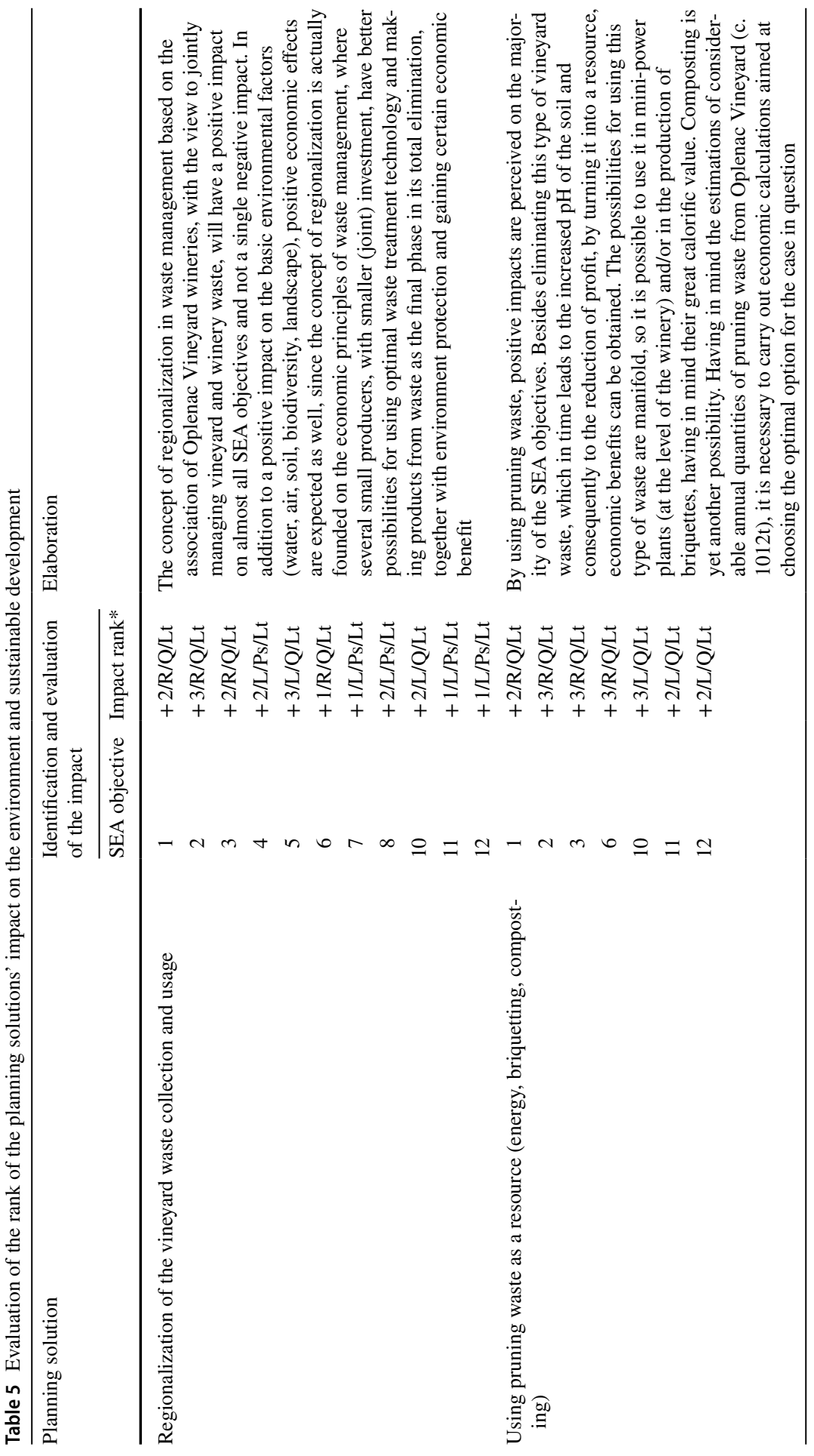




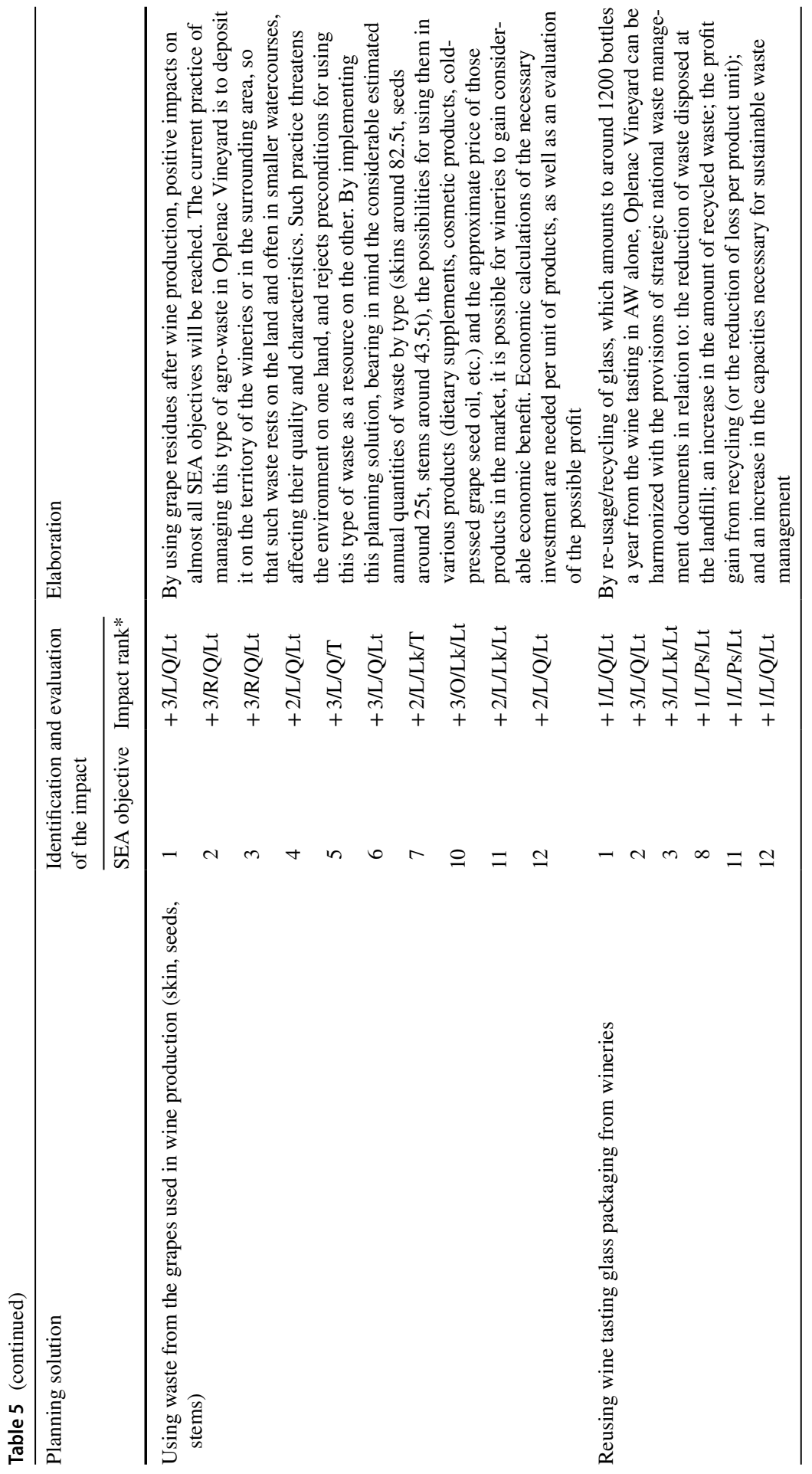




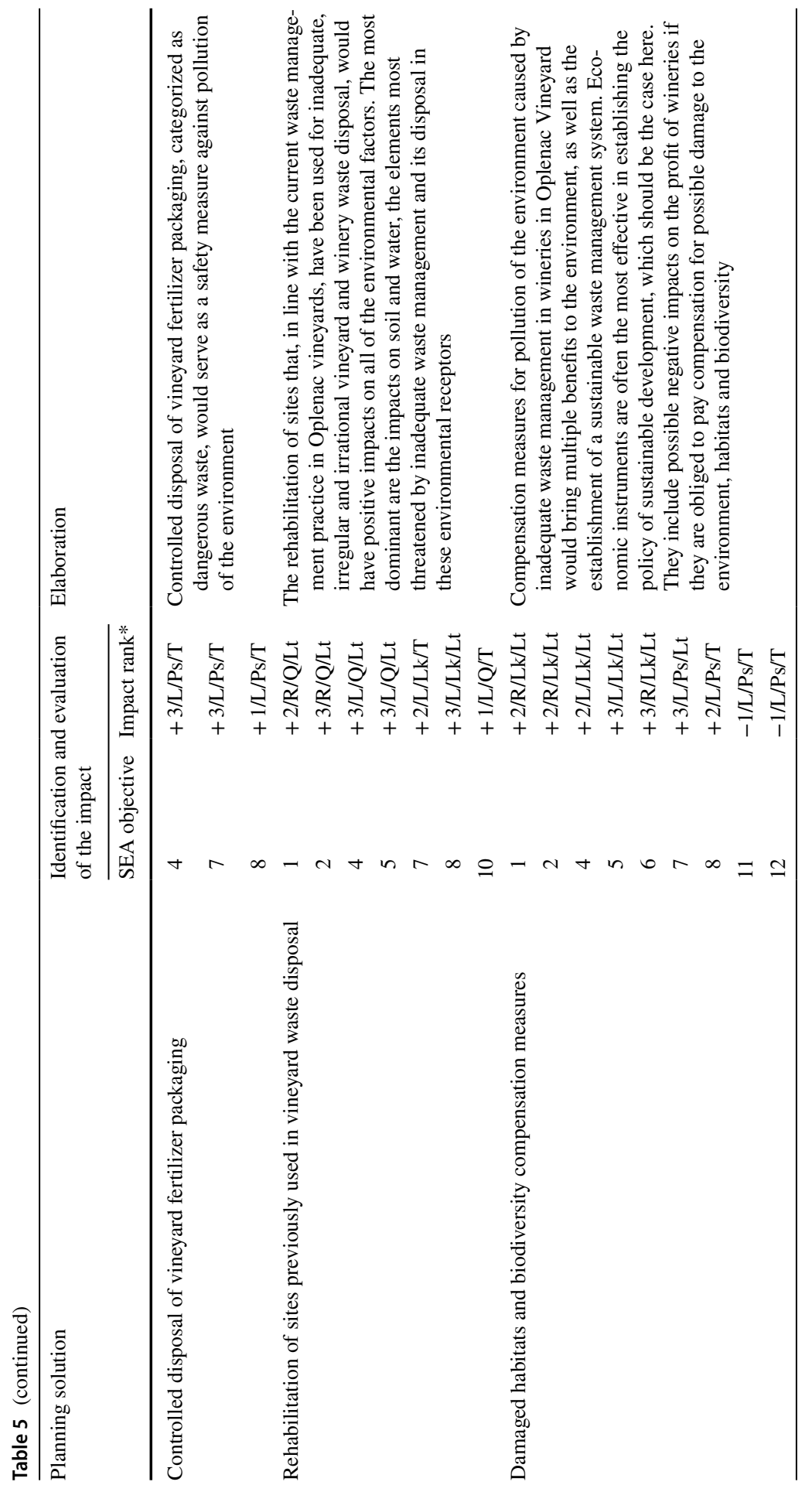




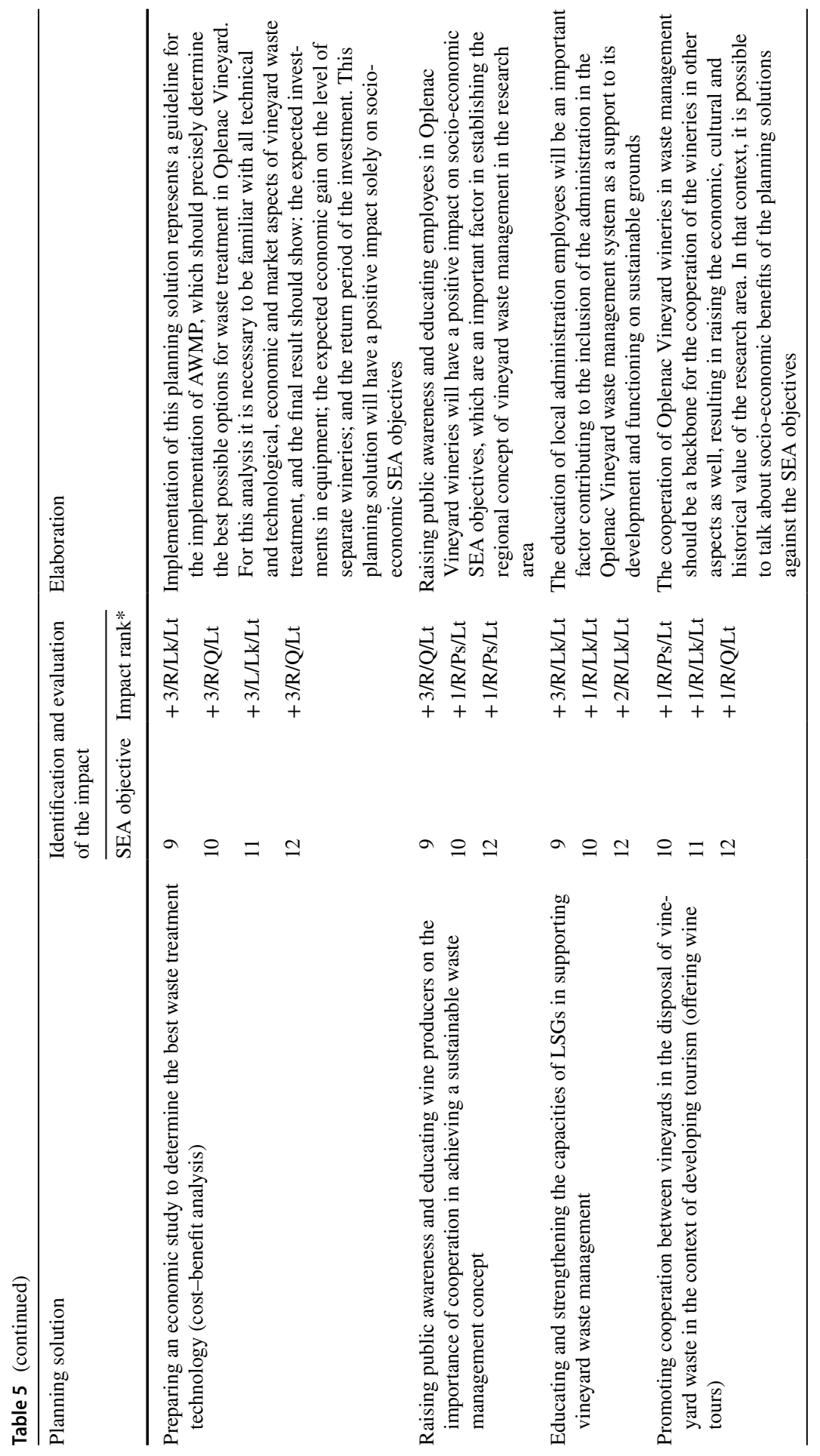




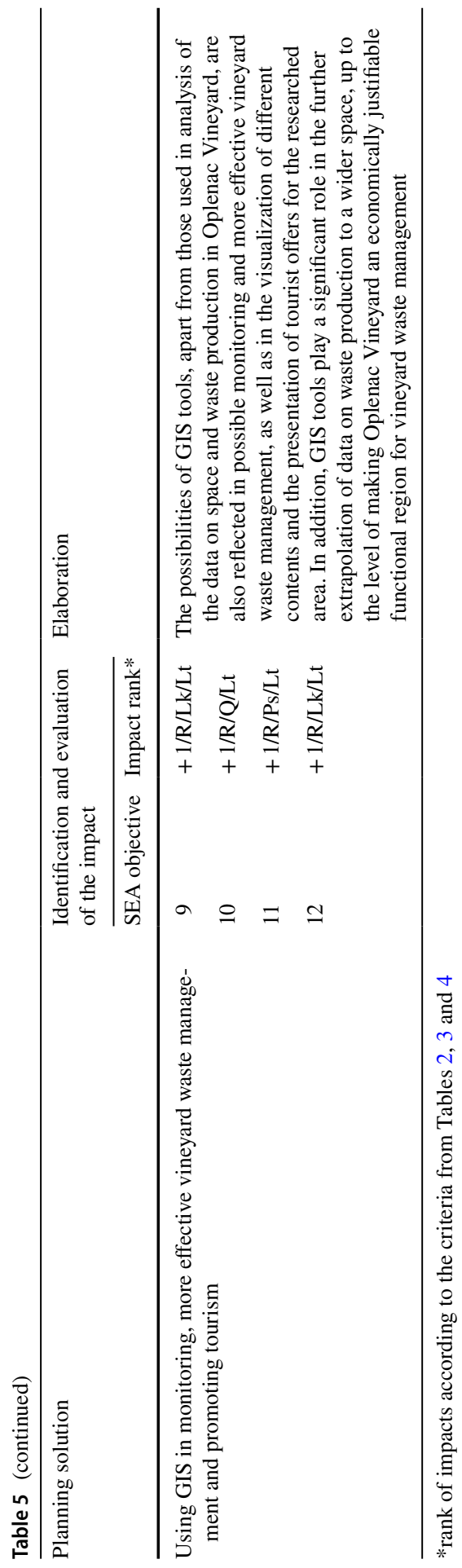


a

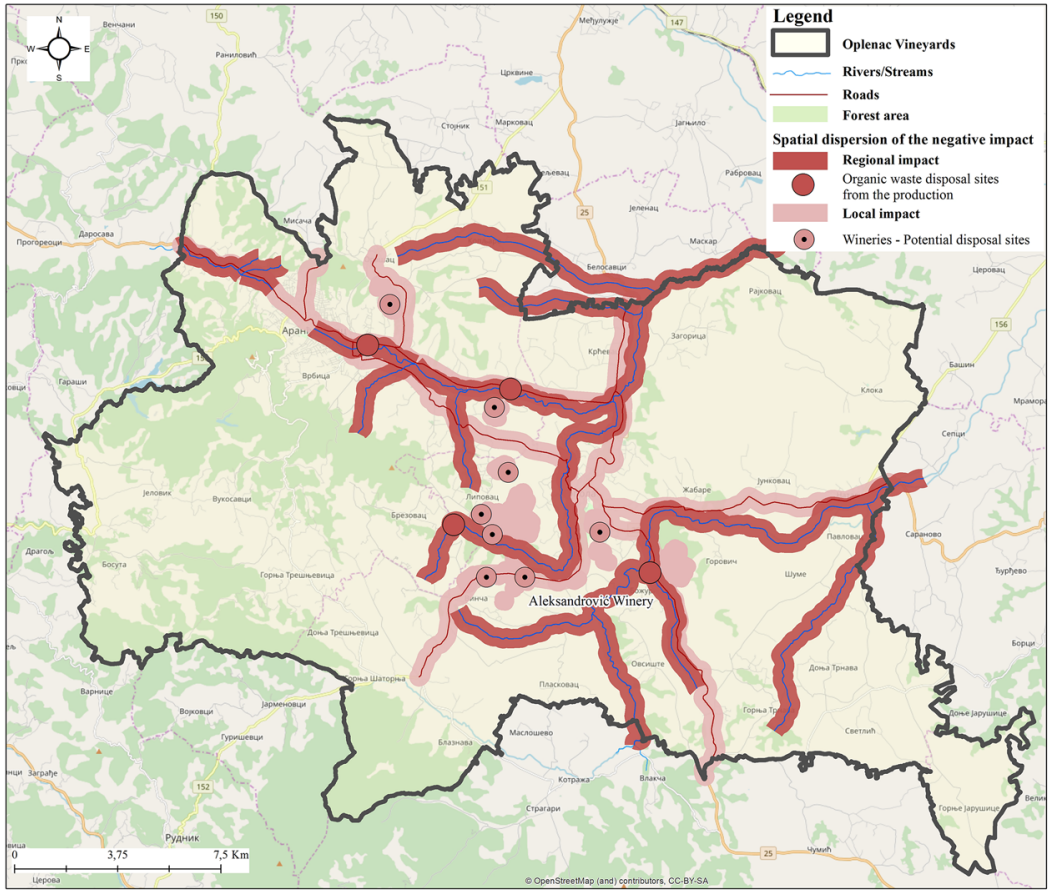

b

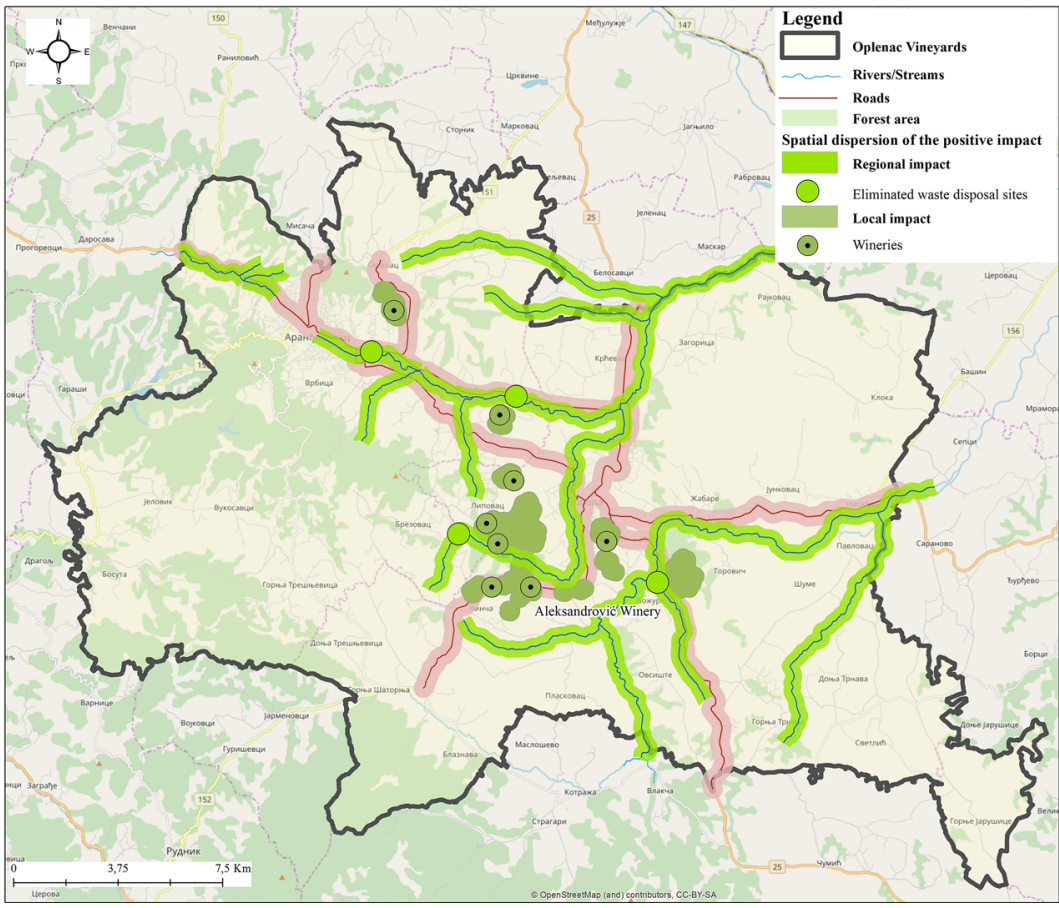

Fig. 3 a Territorial impacts of the vineyards on the environment before AWMP implementation. b Territorial impacts of the vineyards on the environment after AWMP implementation 


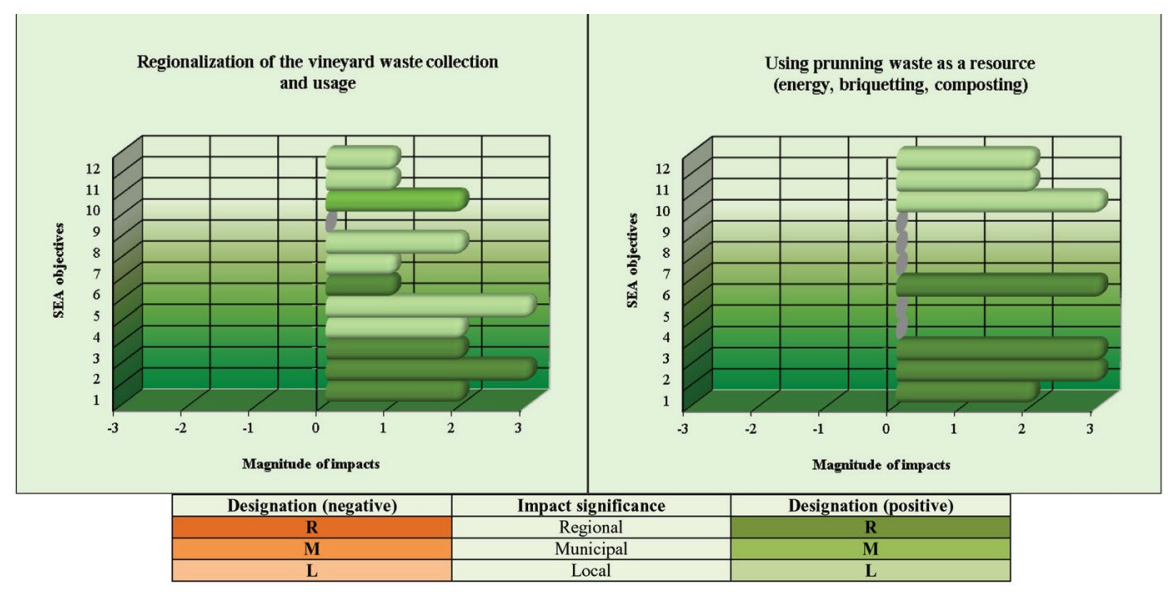

Fig. 4 Graphic presentation of evaluation results

on one hand educated, and on the other are given a good basis for making decisions on future developments in the field of managing agricultural waste from wineries and viticulture. In this case study, decisions are predominantly in the hands of winery owners, who should team up on a regional basis in waste management. Winery profits are usually the highest priority, so solutions that only address environmental benefits are not sufficient motivation in themselves, rather it is also important to consider the economic satisfaction gained from introducing modern waste management principles. Therefore, the educational character of the results of the MCE method used in the SEA process is of particular importance. It is presented in this paper in the matrices and graphs (Fig. 4) for evaluating the planning solutions, particularly in Table 5, which identifies and evaluates the ranks of the planning solutions with regard to their environmental impact and sustainable development. The results show the market value of individual products that can be obtained from organic waste, as well as the total amount of this type of waste in the region, so it is possible to make a rough estimate of the potential profits that the owners of wineries could expect by applying the planning proposals from the AWMP for Oplenac Vineyard.

Although the object of this paper was not to show the complete SEA process, it is important to emphasize that based on the results obtained from applying the MCE method within the framework of the SEA study, appropriate guidelines were defined that should ensure the consistent implementation of planning solutions that have positive effects on SEA goals, that is, they minimize the potential negative effects on the space they refer to. Once the guidelines and monitoring measures that need to be implemented in the AWMP are formulated in the SEA study, it is ready for the decision-making process. Bearing in mind that a simulated AWMP was used in this study for Oplenac Vineyard, at this moment the decision-making phase in the application of the AWMP has not been envisaged, but rather, it will initially have an educational character in eight wineries belonging to Oplenac Vineyard. In the context of education, winery owners can at this stage already decide to apply specific technological solutions that apply to the use of waste as a resource, all for the purpose of 
applying the principles of a circular economy, sustainable development and protection of the environment. In this case, Aleksandrović Winery (the case study) has, using the research results and information shown in Table 5, recognized the benefits of applying the proposed concept and has already begun to put the research into practice by acquiring and beginning to use equipment for the collection and treatment of waste from pruning, as well as launching an initiative to associate with other wineries in Oplenac Vineyard in order to achieve the best effects by applying the principles of a circular economy. In this way, the research acquired an applicative character.

\section{Conclusion}

The assessment of spatial/territorial environmental impacts using SEA is in its early stages in the development of spatial development policy in general, including sustainable waste management policy, which is a significant segment of spatial development. This paper presents the specifics and possibilities in relation to applying MCE methods in SEA for the AWMP of Oplenac Vineyard, supported by GIS tools. The specifics are: the selection of relevant objectives and indicators for evaluating the planning solutions that, in addition to environmental, include socio-economic aspects of sustainable development; the role of GIS tools in the spatial analysis, evaluation and perception of planning solutions in relation to the spatial dispersion of impacts and presentation of the solutions from the SEA process; and the method used to present the planning solutions in the form of matrices and graphs.

Considering that the strategic planning phase, for example the AWMP, does not directly produce any relevant technical, technological, economic or other detailed data, it is not possible to apply various multi-criteria simulation and mathematical decision-making methods, such as Additive Ratio Assessment (ARAS) or the Analytical Hierarchy Process (AHP) (Fu 2019; Improta et al. 2018; Kutut et al. 2014). These methods are used in other instruments in the field of environmental protection (EIA, ESIA) that are a natural continuation of the SEA process, and they minimize subjectivity in impact assessment, but are outside the SEA mandate according to European Strategic Environmental Assessment Directive 2001/42/EC.

In order to minimize subjectivity in the SEA process, it is extremely important, wherever possible, to support the SEA process by using different software models and methods to determine the territorial impacts, which in this case was achieved using GIS tools. The MCE method served as a means of determining: the impact intensity; spatial dimension of the impact; impact probability; and duration of the impact. The defined MCE criteria helped to identify the impacts of the AWMP, and the evaluation results were presented in a clear way based on GIS visualization, matrices and graphs, which proved particularly suitable in an educational context and later showed significant potential in decision making on the future conception of development.

Bearing in mind the solutions for eliminating agricultural waste from wineries and viticulture proposed in the AWMP for Oplenac Vineyard and the possibility of further extrapolation of data using GIS, it is possible to determine the spatial 
coverage using technical and economic instruments and life-cycle assessment (EIA, ESIA, LCA), which would provide opportunities for achieving the most favorable, above all economic, solutions, as the most efficient initiators of the initiative to bring together several wineries in order to apply the principles of a circular economy. The benefit would thus be economic, but also in the area of environmental protection. Although this type of economic analysis is outside the scope of SEA, this approach creates good preconditions for achieving the conceived solutions in the implementation phase of the AWMP. The possibility of making predictions in fields beyond the scope of SEA by means of spatial analyses in GIS indicates the flexibility of the method adopted, based on the modern principles of a circular economy and sustainability in general, and it provides opportunities for further research in the territorial management of agricultural waste as a very important resource, especially thanks to the joint application of SEA and GIS instruments. Although in this research GIS was primarily used as a supporting tool, spatial data collected through this process could contribute to establishing an integral waste management system. This system could be implemented and adjusted on a national or broad regional scale. Some of the findings of recent studies (Krunić et al. 2019) support the possibility of combining geospatial data with other data and indicators on a national level in winegrowing regions, in order to identify the main flows of agro-waste in Serbia. This is certainly a comparative advantage over current SEA implementation practices.

The methodological approach presented is potentially applicable to a wide range of development documents, where the focus should be to increase objectivity in the process of evaluating strategic development documents.

Returning to the role of environmental protection and the application of SEA in the context of addressing ethical and moral issues related to spatial development, agricultural waste management and development in general, it has already been pointed out that the SEA is a decision-making instrument. Regardless of the ethical and moral principles that experts adhere to in the SEA process, experts are not decision makers. Decision makers are institutions, politicians, investors, etc. Their ethical and moral values do not have to be, and often are not in the same "coordinate system" as science and professionals, so in that context the limited possibilities of the SEA process can be seen in terms of reaching certain ethical standards when it comes to implementing the conceived solutions. In addition, the fact pointed out by Callicott (2018) is that ethical and moral attitudes depend on the circumstances (spatial, temporal, cultural, etc.) in which we live. Circumstances are changing, and so are ethical, and often moral attitudes, so there is always uncertainty as to how positions formed today in SEA, or in environmental policy in general, will have value and applicability tomorrow. Regardless of the views expressed, living in the present, analyzing the past, and thinking about the future, it is necessary to constantly raise the level of ethical and moral standards in the application of SEA, thus increasing the possibility for the majority of the conceived solutions, in this case in the field of the circular (agro conomy, to be applied in practice. The objectivity of the SEA process will certainly contribute to this, which is achieved by the methodological approach presented in this paper and by including the GIS technique in the analysis and presentation of the results. An additional value and opportunity for ethical and moral codes to be accepted by SEA decision makers is public participation within 
the SEA process, through which it is possible to debate the proposed solutions, and in such a way influence the decision makers to make decisions in accordance with high moral and ethical standards.

Acknowledgements This work was carried out within the framework of the NoAW project, which is supported by the European Commission through the Horizon2020 research and innovation program under Grant Agreement No. 688338. The authors would like to acknowledge Prof. Nathalie Gontard (project coordinator, INRA, France), Anna Ekman Nilsson (WP2 leader, RISE, Sweden) and Burkhard Schaer (WP1 leader, ECOZEPT, Germany) for their help and wonderful collaboration. Also, the paper presents the results of the research carried out on Project TR 36036- "Sustainable spatial development of the Danube area in Serbia"; and on Project TR 36035- "Spatial, ecological, energy, and social aspects of settlement development and climate change-mutual impacts", both financed by the Ministry of Education and Science of the Republic of Serbia.

Data Availability The data supporting the findings of this study are freely available in 'Spatial/territorial analysis as support to AWMP and SEA for the selected case study area', accessible at https://doi. org/10.15454/HOTPJB.

Open Access This article is licensed under a Creative Commons Attribution 4.0 International License, which permits use, sharing, adaptation, distribution and reproduction in any medium or format, as long as you give appropriate credit to the original author(s) and the source, provide a link to the Creative Commons licence, and indicate if changes were made. The images or other third party material in this article are included in the article's Creative Commons licence, unless indicated otherwise in a credit line to the material. If material is not included in the article's Creative Commons licence and your intended use is not permitted by statutory regulation or exceeds the permitted use, you will need to obtain permission directly from the copyright holder. To view a copy of this licence, visit http://creativecommons.org/licen ses/by/4.0/.

\section{References}

Acosta-Alba, I., Chia, E., \& Andrieu, N. (2019). The LCA4CSA framework: Using life cycle assessment to strengthen environmental sustainability analysis of climate smart agriculture options at farm and crop system levels. Agricultural Systems, 171, 155-170. https://doi.org/10.1016/j.agsy.2019.02.001.

Ahlgren, S., Björklund, A., Ekman, A., Karlsson, H., Berlin, J., Börjesson, P., et al. (2015). Review of methodological choices in LCA of biorefi nery systems-key issues and recommendations. Biofpr, 9(5), 606-619. https://doi.org/10.1002/bbb.1563.

Ananda, J., \& Heralth, G. (2009). A critical review of multi-criteria decision-making methods with special reference to forest management and planning. Ecological Economics, 68(10), 2535-2548. https ://doi.org/10.1016/j.ecolecon.2009.05.010.

Arnaudova, Z., \& Bileva, T. (2011). The use of GIS to support sustainable management of vineyards in Plovdiv, Bulgaria. Communications in Agricultural and Applied Biological Sciences, 76, 355-361.

Badr, G., Hoogenboom, G., Moyer, M., Keller, M., Rupp, R., \& Davenport, J. (2018). Spatial suitability assessment for vineyard site selection based on fuzzy logic. Precision Agriculture, 19, 1027-1048.

Balfors, B., Wallström, J., Lundberg, K., Söderqvist, T., \& Högström, J. (2018). Strategic environmental assessment in Swedish municipal planning. Trends and challenges. Environmental Impact Assessment Review, 73, 152-163. https://doi.org/10.1016/j.eiar.2018.07.003.

Banville, C., Landry, M., Martel, J. M., \& Boulaire, C. (1998). A stakeholder approach to MCDA. Systems Research and Behavioral Science, 15(1), 15-32. https://doi.org/10.1002/(SICI)10991743(199801/02)15:1\%3c15::AID-SRES179\%3e3.0.CO;2-B.

Biarnès, A., Bailly, J. S., \& Boissieux, Y. (2009). Identifying indicators of the spatial variation of agricultural practices by a tree partitioning method: The case of weed control practices in a vine growing catchment. Agricultural Systems, 99, 105-116. https://doi.org/10.1016/j.agsy.2008.10.002. 
Brown, A. L., \& Therivel, R. (2000). Principles to guide the development of strategic environmental assessment. Impact Assessment and Project Appraisal, 18, 183-189. https://doi.org/10.3152/147154600781767385.

Buttel, F. H. (1996). The spirit of the soil: Agriculture and Environmental Ethics Paul B Thompson Routledge, London and New York, 1995, 196 pp. Land Use Policy, 13(3), 235-236. https://doi. org/10.1016/0264-8377(96)84063-4.

Callicott, J. B. (2018). Environmental Ethics. Encyclopedia of the Anthropocene, 4, 1-10. https://doi. org/10.1016/B978-0-12-809665-9.10303-9.

Chaker, A., El-Fadl, K., Chamas, L., \& Hatjian, B. (2006). A review of strategic environmental assessment in 12 selected countries. Environmental Impact Assessment Review, 26(1), 15-56. https://doi. org/10.1016/j.eiar.2004.09.010.

Coulon-Leroy, C., Charnomordic, B., Thiollet-Scholtus, M., \& Guillaume, S. (2013). Imperfect knowledge and data-based approach to model a complex agronomic feature-Application to vine vigor. Computers and Electronics in Agriculture, 99, 135-145.

Dalal-Clayton, B., \& Sadler, B. (2005). Strategic environmental assessment: A sourcebook and reference guide to international experience. London: Earthscan. https://doi.org/10.1142/S146433320 5002274.

De Marchi, B., Funtowicz, O., Lo Cascio, S., \& Munda, G. (2000). Combining participative and institutional approaches with multicriteria evaluation. An empirical study for water issues in Troina, Sicily. Ecological Economics, 34, 267-282. https://doi.org/10.1016/S0921-8009(00)00162-2.

Directive 2001/42/EC of the European Parliament and the Council of 27 June 2002 on the assessment of the effects of certain plans and programmes on the environment, Official Journal 197 of 21 July 2001

Dzwonkowska, D. (2017). Environmental Ethics in Poland. Journal of Agriculture and Environmental Ethics, 30, 135-151. https://doi.org/10.1007/s10806-017-9659-6.

Fahlquist, J. N. (2009). Moral responsibility for environmental problems-Individual or institutional? Journal of Agriculture and Environmental Ethics, 22, 109-124. https://doi.org/10.1007/s1080 6-008-9134-5.

Fu, Y.-K. (2019). An integrated approach to catering supplier selection using AHP-ARAS-MCGP methodology. Journal of Air Transport Management, 75, 164-169. https://doi.org/10.1016/j.jairt raman.2019.01.011.

Hanandeh, A. E., \& Gharaibeh, M. A. (2016). Environmental efficiency of olive oil production by small and micro-scale farmers in northern Jordan: Life cycle assessment. Agricultural Systems, 148, 169-177. https://doi.org/10.1016/j.agsy.2016.08.003.

Improta, G., Russo, M. A., Triassi, M., Converso, G., Murino, T., \& Santillo, L. C. (2018). Use of the AHP methodology in system dynamics: Modelling and simulation for health technology assessments to determine the correct prosthesis choice for hernia diseases. Mathematical Biosciences, 299, 19-27. https://doi.org/10.1016/j.mbs.2018.03.004.

Jakku, E., \& Thorburn, P. J. (2010). A conceptual framework for guiding the participatory development of agricultural decision support systems. Agricultural Systems, 103, 675-682. https://doi. org/10.1016/j.agsy.2010.08.007.

Jeong, J. S. (2018). Design of spatial PGIS-MCDA-based land assessment planning for identifying sustainable land-use adaptation priorities for climate change impacts. Agricultural Systems, 167, 61-71. https://doi.org/10.1016/j.agsy.2018.09.001.

Jones, G. V., Snead, N., \& Nelson, P. (2004). Modeling viticultural landscapes: A GIS analysis of the terroir potential in the Umpqua Valley of Oregon. In Geology and wine (pp. 167-178). St. John's: Geoscience Canada.

Josimović, B., Marić, I., \& Milijić, S. (2015). Multi-criteria evaluation in strategic environmental assessment for waste management plan, A case study: The city of Belgrade. Waste Management Journal, 36, 331-342. https://doi.org/10.1016/j.wasman.2014.11.003.

Josimović, B. (2020). Spatial aspects of the impact of wind farms on the environment. Belgrade, Serbia: IAUS. http://raumplan.iaus.ac.rs/handle/123456789/545

Josimović, B., Cvjetić, A., \& Furundžić, D. (2021). Strategic Environmental Assessment and the precautionary principle in the spatial planning of wind farms-European experience in Serbia. Renewable and Sustainable Energy Reviews. https://doi.org/10.1016/j.rser.2020.110459.

Jurisic, M., Stanisavljevic, A., \& Plascak, I. (2010). Application of Geographic Information System (GIS) in the selection of vineyard sites in Croatia. Bulg. J. Agric. Sci., 16, 235-242.

Kamali, F. P., Borges, J. A. R., Meuwissena, M., de Boer, I., \& Lansink, A. (2017). Sustainability assessment of agricultural systems: The validity of expert opinion and robustness 
of a multi-criteria analysis. Agricultural Systems, 157, 118-128. https://doi.org/10.1016/j. agsy.2017.07.013.

Kangas, J., \& Kangas, A. (2005). Multiple criteria decision support in forest management the approach-methods applied, and experiences gained. Forest Ecology and Management, 207, 133143. https://doi.org/10.1016/j.foreco.2004.10.023.

Keong, C. Y. (2021). The nexus of environmental ethics and environmental sustainability: An empirical assessment. In C. Y. Keong (Ed.), Global environmental sustainability-Case studies and analysis of the United Nations' Journey toward sustainable development (pp. 253-288). Amsterdam: Elsevier. https://doi.org/10.1016/B978-0-12-822419-9.00005-9.

Kirchherr, J., \& Piscicelli, L. (2019). Towards an education for the circular economy (ECE): Five teaching principles and a case study. Resources, Conservation \& Recycling, 150, 104406. https://doi. org/10.1016/j.resconrec.2019.104406.

Krunić, N., Josimović, B., Gajić, A., \& Nenković-Riznić, M. (2019). Territorial analysis as support to strategic environmental assessment process for agro-waste management plan. Spatium, 42, 16-22. https://doi.org/10.2298/SPAT1942016K.

Kutut, V., Zavadskas, E. K., \& Lazauskas, M. (2014). Assessment of priority alternatives for preservation of historic buildings using model based onARAS and AHP methods. Archives of Civil and Mechanical Engineering, 14, 287-294. https://doi.org/10.1016/j.acme.2013.10.007.

Laurent, A., Clavreul, J., Bernstad, A., Bakas, I., Niero, M., Gentil, E., et al. (2013). Review of LCA studies of solid waste management systems-Part II: Methodological guidance for a better practice. Waste Management. https://doi.org/10.1016/j.wasman.2013.12.004.

Leite, J. G. D. B., Justino, F. B., Silva, J. V., Florin, M., \& Van Ittersum, M. (2015). Socioeconomic and environmental assessment of biodiesel crops on family farming systems in Brazil. Agricultural Systems, 133, 22-34. https://doi.org/10.1016/j.agsy.2014.10.005.

Liou, M. L., Yeh, S. C., \& Yu, Y. H. (2006). Reconstruction and systemization of the methodologies for strategic environmental assessment in Taiwan. Environmental Impact Assessment Review, 26, 170-184. https://doi.org/10.1016/j.eiar.2005.08.

Maričić, T., \& Josimović, B. (2005). Overview of Strategic Environment Assessment /SEA/ system in Southeast Europe. Arhitektura i urbanizam, 16-17, 66-74. http://raumplan.iaus.ac.rs/handle/123456789/81

Marsden, S. (2002). Strategic environmental assessment: an international overview. In S. Marsden \& S. Dovers (Eds.), Strategic environmental assessment in Australasia (pp. 1-23). Alexandria: The Federation Press. https://doi.org/10.1142/S1464333202000929.

Miller, L. F. (2018). How ecology can edify ethics: The scope of morality. Journal of Agricultural and Environmental Ethics, 31, 443-454. https://doi.org/10.1007/s10806-018-9738-3.

Munda, G. (2008). Social Multi-criteria Evaluation for Sustainable Economy. Cham: Springer. https:// doi.org/10.1007/978-3-540-73703-2.

National list of environmental indicators, 2011. The official gazette of the Republic of Serbia, No 37/2011.

Nenković-Riznić, M., Josimović, B., \& Milijić, S. (2014). SEA as instrument in responsible planning of tourist destinations. Case Study of Djerdap National Park, Serbia. Journal of Environmental and Tourism Analyses, 2(1), 5-18. http://raumplan.iaus.ac.rs/handle/123456789/574

Nilsson, M., Björklund, A., Finnveden, G., \& Johansson, J. (2005). Testing a SEA methodology for the energy sector: A waste incineration tax proposal. Environmental Impact Assessment Review, 25, 1-32. https://doi.org/10.1016/j.eiar.2004.04.003.

Nilsson, M., \& Dalkmann, H. (2001). Decision-making and strategic environmental assessment. Journal of Environmental Assessment Policy and Management, 3, 305-327. https://doi.org/10.1142/S146433320 1000728.

Noble, B., \& Nwanekezie, K. (2017). Conceptualizing strategic environmental assessment: Principles, approaches and research directions. Environmental Impact Assessment Review, 62, 165-173. https:// doi.org/10.1016/j.eiar.2016.03.005.

Nowlin, J. W., \& Bunch, R. L. (2016). A model for selecting viticultural sites in the piedmont triad region of North Carolina. International Journal of Applied Geospatial Research (IJAGR), 7(3), 38-70. https://doi.org/10.4018/IJAGR.2016070102.

O'Brien, D., Bohan, A., McHugh, N., \& Shalloo, L. (2016). A life cycle assessment of the effect of intensification on the environmental impacts and resource use of grass-based sheep farming. Agricultural Systems, 148, 95-104. https://doi.org/10.1016/j.agsy.2016.07.004.

Peiró, L. T., Polverini, D., Ardente, F., \& Mathieux, F. (2019). Advances towards circular economy policies in the EU: The new Ecodesign regulation of enterprise servers. Resources, Conservation \& Recycling, . https://doi.org/10.1016/j.resconrec.2019.104426. 
Proctor, W., \& Drechsler, M. (2006). Deliberative multicriteria evaluation. Environment and Planning C: Government and Policy, 24, 169-190. https://doi.org/10.1068/c22s.

Rugani, B., Maia de Souza, D., Weidema, B., Bared, J., Bakshi, B., Grann, B., et al. (2019). Towards integrating the ecosystem services cascade framework within the Life Cycle Assessment (LCA) cause-effect methodology. Science of the Total Environment, 690, 1284-1298. https://doi.org/10.1016/j.scitotenv.2019.07.023.

Salhofer, S., Wassermann, G., \& Binner, E. (2007). Strategic environmental assessment as an approach to assess waste management systems. Experiences from an Austrian case study. Environmental Modelling \& Software, 22, 610-618. https://doi.org/10.1016/j.envsoft.2005.12.031.

Sarkkinen, M., Kujala, K., \& Gehör, S. (2019). Decision support framework for solid waste management based on sustainability criteria: A case study of tailings pond cover systems. Journal of Cleaner Production. https://doi.org/10.1016/j.jclepro.2019.07.058.

Sassanelli, C., Rosa, P., Rocca, R., \& Terzi, S. (2019). Circular economy performance assessment methods: A systematic literature review. Journal of Cleaner Production, 229, 440-453. https://doi. org/10.1016/j.jclepro.2019.05.019.

Stefanović, N., Josimović, B., \& Danilović Hristić, N. (2018). Models of implementation of spatial plans: Theoretical approach and case studies for spatial plans for the special purpose area. In Y. B. Ergen (Ed.), An overview of urban and regional planning (pp. 59-81). London: IntechOpen. https://doi. org/10.5772/intechopen.78242.

Suarez-Eiroa, B., Fernandez, E., Mendez-Martínez, G., \& Soto-Onate, D. (2018). Operational principles of circular economy for sustainable development: Linking theory and practice. Journal of Cleaner Production, 214, 952-961. https://doi.org/10.1016/j.jclepro.2018.12.271.

Tzilivakis, J., Broom, C., Lewis, K. A., Tucker, P., Drummond, C., \& Cook, R. (1999). A strategic environmental assessment method for agricultural policy in the UK. Land Use Policy, 16, 223-234.

Um, N., Kang, Y.-Y., Kim, K.-H., Shin, S.-K., \& Lee, Y. (2018). Strategic environmental assessment for effective waste management in Korea: A review of the new policy framework. Waste Management, 82, 129-138. https://doi.org/10.1016/j.wasman.2018.10.025.

UN Indicators of Sustainable Development: Guidelines and Methodologies, 2017. Third Edition.

Unalan, D., \& Cowell, R. (2019). Strategy, context and strategic environmental assessment. Environmental Impact Assessment Review. https://doi.org/10.1016/j.eiar.2019.106305.

White, L., \& Noble, B. (2013). Strategic environmental assessment for sustainability: A review of a decade of academic research. Environmental Impact Assessment Review, 42, 60-66. https://doi. org/10.1016/j.eiar.2012.10.003.

Zionts, S. (1979). MCDM-if not a Roman numeral, then what? Interfaces, 9, 94-101. https://doi. org/10.1287/inte.9.4.94.

Zionts, S., \& Wallenius, J. (1976). An interactive programming method for solving the multiple criteria problem. Management Science, 22, 652-663. https://doi.org/10.1287/mnsc.22.6.652.

Publisher's Note Springer Nature remains neutral with regard to jurisdictional claims in published maps and institutional affiliations.

\section{Authors and Affiliations}

\section{Boško Josimović ${ }^{*}$ Nikola Krunić ${ }^{\text {· Aleksandra Gajić }}{ }^{1}$ - Božidar Manić ${ }^{1}$}

Boško Josimović

bosko@iaus.ac.rs

1 Institute of Architecture, Urban and Spatial Planning of Serbia, Bulevar kralja Aleksandra 73, Belgrade, Serbia 